\title{
Original Article \\ MEMBRANE POTENTIAL CHANGE EFFECTS ON CATIONIC AND NEUTRAL DRUG - INDUCED ERYTHROCYTE SHAPE CHANGE AND CELLULAR UPTAKE OF DRUGS.
}

\author{
NWAFOR A AND COAKLEY W. T \\ ${ }^{1}$ Department of Human Physiology, College of Health Sciences University Of Port Harcourt, \\ Nigeria \\ ${ }^{2}$ School of Pure and Applied Biology University of Wales, College of Cardiff, Cathay's Park, \\ Cardiff, U.K.
}

\begin{abstract}
The effect of membrane potential change of the human erythrocytes on cationic drugs tetracaine and chlorpromazine and neutral drug benzyl alcohol induced cell shape change and red cell uptake of drug has been quantitated using light microscopy and spectrophotometry respectively. At the drug concentration necessary to cause cell membrane cell shape change membrane potential change from $-7.1 \mathrm{mV}$ to $16.4 \mathrm{mV}$ let to the reversal of the cup-forming property of chlorpromazine and tetracaine to that of a crenetor at both $20^{\circ} \mathrm{C}$ and $37^{\circ} \mathrm{C}$. The effect of altering the membrane potential from -7. $\operatorname{ImV}$ to $16.4 \mathrm{mV}$ also led to the decrease of cellular uptake of drug with increasing membrane diffusion potential. The membrane potential dependent drug induced cell shape change with also reversible on reversing the membrane potential. The results therefore suggest that the cellular uptake of drug and drug induced cell shape change in human erythrocytes was dependent on change in extracellular chloride concentration
\end{abstract}

Key words: Membrane potential, cationic drugs, drug uptake, blood, human.

${ }^{*}$ Author for Correspondence

\section{INTRODUCTION}

Glaser (1979, 1982) found some correlation between the membrane potential of human erythrocytes and the discocyte -echionocyte and the discocyte - stomatocyte transformation. The membrane potential was changed by alteration in $\mathrm{pH}$ of the suspending phase or by ionophore treatment. Nwafor and Coakley $(1985,1991)$ pointed out that there was some relationship between membrane potential of human erythrocytes and drug induced cell shape change. In the study membrane potential was changed by reducing the extracellular chloride concentration significantly while maintaining the ionic strength and the osmolarity of the cell suspending solution constant. Cell volume changes are in principle undersirable in systems in which cell morphology is studied (Nwafor and Cockley 1991). The influence of transmembrane potential on cellular uptake of drug has not been properly quantitated.
Mohandas and Feo (1975) studied the uptake of anionic and cationic derivatives of phenothiazine by the red blood cells and pointed out that there was some correlation between cellular uptake and red cell morphology Sheetz and Singer (1974), Kanaho et al (1981) observed that ghosts and intact erythrocytes undergo very similar drug induced shape changes. Their studies led to the suggestion that membrane potential of human erythrocytes was not of primary importance to the observed shape changes. However, the studies were carried out at extracellular chloride contraction around $130 \mathrm{mV}-145 \mathrm{mV}$ $\mathrm{NaC} 1(-4.2 \mathrm{mV}$ to -7 . ImV).

In the present study we report spme observation on the contribution that membrane potential make on cellular uptake of cationic drugs chlopromajine and tetraceine (Deuticke 1968 Fuji et al 1976) and neutral drug benzyl alcohol (Deuticke, 1968) with their effects on the morphology of human erythrocytes at $\mathrm{E}=$ 
-7. ImV (145mM NaC1) to $E=16.4 m V$ (60mM NaC1) (Nwafor and Cockley 1989, 1991).

\section{MATERIALS AND METHODS}

\section{Composition of erythrocytes suspending solutions:}

The compositions of the erythrocyte suspending solutions of sodium chloride with sorbitol/sodium buffered with $5 \mathrm{mM}$ Hepes at $\mathrm{pH}$ calculated to keep the intracellular chloride ion concentrations and cell volume constant has been described elsewhere (Nwafor and Coakley, 1991). Briefly, buffered $\mathrm{NaCl} /$ sorbitol $\mathrm{NaCl} / \mathrm{Na}$ gluconate solutions were prepared with $5 \mathrm{mM}$ Hepes as follows: $145 \mathrm{mM} \mathrm{NaC1}$ with $5 \mathrm{mM}$ Hepes, $\mathrm{pH}$ 7.32, diffusion potential $\mathrm{E},-7.14 \mathrm{mV}$ and $60 \mathrm{mM} \mathrm{NaC} 1$ with $170 \mathrm{mM}$ sorbitol (or $85 \mathrm{mM}$ sodium gluconate with $5 \mathrm{mM}$ Hepes, $\mathrm{pH} 6.94$, diffusion potential $\mathrm{E}=16.43 \mathrm{mV}$.

\section{Preparation of buffered solutions of drugs:}

Cationic drugs (chlorpromazine hydrochloride, tetracaine hydrochloride and neutral drug benzyl alcohol (BDH chemicals) were used for the study. The chemical to be tested was dissolved in the buffer and the $\mathrm{pH}$ of the drug solution was adjusted to the value determined for the buffer by addition of $1 \% \mathrm{NaOH}$. The concentration of the drug solutions was assessed spectrphotometrically using an S.P 1805 Unicam double beam spectrophotometer (Unicam Ltd. England) and their Ultraviolet absorption wavelength $(\mathrm{mm})$ were obtained as follows. benzyl acohol 259, chlopromasine HCL 254 and tetracenic HCL 310.

\section{Light Microscopy:}

Cell suspension ( $5 \times 10$ cells $/ \mathrm{ml})$ in drug solution and glularaldehyde in buffer $(0.5 \%$, vtv) were maintained at the same temperature of eithet or $37^{\circ} \mathrm{C}$. Following exposure of the cells to drug for a known time, $\quad 0.2 \mathrm{~m} 1$ of the glutaraldehyde solution was added to 1 .Oml of cell suspension. The cell suspension was then allowed to stand at the desired temperature of at least 3 minutes. A sample of the fixed cell suspension was draw by surface tension unto $5.0 \mathrm{~cm}$ long glass microcapillaries of rectangular cross-section $0.2 \mathrm{~mm}$ pathlength and $1.2 \mathrm{~mm}$ width and observed using Normaski differential interference contrast with a $\times 100$ oil immersion objective on a Nachet 400 microscope (Nwafor and Coakley 1985, 1986). The initial erythrocyte shape change $(0 \mathrm{~mm})$ was determined as described elsewhere (Nwafor and Coakley 1986), the erythrocyte shape were characterized according to the criteria proposed by Fujii et al (1979), Deuticke

(1968).

\section{Measurement of cellular uptake of drugs and preparation of blood suspension:}

Various blood was collected into acid! citrate !dextrose. 1.0 to $5.0 \mathrm{ml}$ of the cell suspension media $(145 \mathrm{mM} \mathrm{NaCl} 5 \mathrm{mM}$ Hepes, pH 7.32 or $60 \mathrm{mM} \mathrm{NaCl} 170 \mathrm{mM}$ sorbitol $5 \mathrm{mM} \mathrm{H} \mathrm{pH}$ 6.94). The cell suspension was washed and the washed cells were resuspended in $1 \mathrm{Oml}(\mathrm{V})$ of the same buffer containing a known concentration of drug or without drug (control). The percentage of the collected whole cells to the total volume of the cell suspension was estimated by the relationship:

Haematocrit $\mathrm{H}(\%)=\frac{\mathrm{PCV}+\mathrm{N} \times 100}{\mathrm{PCV}+(\mathrm{N}+\mathrm{V})}$

Where PCV, packed cell volume, was taken to be $0.45 \%$ Cell pellets washed as described below were resuspended in buffer containing a known drug concentration and maintained at $37^{\circ} \mathrm{C}$ for $10 \mathrm{~min}$ in a thermostat controlled water bath. After $10 \mathrm{~mm}$ the suspension was centrifuged at $3,5 \mathrm{OOg}$ for five minutes in a bench centrifuge at $37^{\circ} \mathrm{C}$ and the supernatant was carefully collected. The absorbance of the initial drug solution (OD') was measured against a buffer blank at the appropriate ultraviolet absorption wavelength of the drug tested. The absorbance of the supernatant (OD was measured against the supernatant of the control cell in order to reduce any 
interference of haemoglobin with the results.

The absorbance measurements were obtained with S.P. 1805 Unican double beam spectrophotometer. The percentage drug uptake by erythrocytes was calculated as the difference in absorbance $\mathrm{OD}$ and $\mathrm{OD}$ expressed as a percentage of the initial drug solution $\left(\mathrm{OD}_{1}\right)$ i.e

Change in absorbance $(\%)=\frac{\mathrm{OD}_{1}}{1} \frac{-\mathrm{OD}_{2}}{\mathrm{OD}_{1}} \underline{\times 100}$

The absorption of the drugs reached equilibrium in less than two minutes and no difference in the absorbance value was detected with increasing time up to 60 minutes.

\section{RESULTS}

The influence of transmembrane potential on cellular uptake of drugs:

Table la shows the effect of different extracellular chloride concentration on cellular uptake of tetracaine, chlorpromazine and benzyl alcohol. Erythrocytes exposed to cationic drugs at membrane diffusion potential, $\mathrm{E},=16.4$ $\mathrm{mV}$ had low cellular uptake of drug compared with cells at E - 7. ImV. There was only a small difference in uptake of benzyl alcohol by erythrocytes in the two isotonic solutions. Generally, the partitioning of the positively charged drugs - tetracaine and chlorpromazine and neutral drug benzyl alcohol across the membrane decreased with increasing membrane potential.

The ratio of cellular uptake of tetracaine, chlorpromazine and benzyl alcohol for a constant extracellular drug concentration by erythrocytes at 145 $\mathrm{NaC} 1$ to $60 \mathrm{mM} \mathrm{NaCl}$ for the different drugs and haematocrits, has the values given by column 5 of table la. The ratio of the values for the distribution of the drugs across the membrane calculated at 145 $\mathrm{mM} \mathrm{NaC1}$ and $60 \mathrm{mM} \mathrm{NaCl}$ at constant haematocrit gave the relative change in intracellular concentatration of drug for constant extracellular chloride concentration.

\section{Drug induced erythrocyte shape change: Chlorpromazine:}

The percentage stage III internalized cells scored for cells maintained with $0.1 \mathrm{mM}$ chlorpromazine in $60 \mathrm{mM} \mathrm{NaCl}$ at $37^{\circ} \mathrm{C}$ was highest immediately and then fell gradually with time. The initial peak following exposure of cell, to drug in 145 $\mathrm{mM} \mathrm{NaC1}$ at $37^{\circ} \mathrm{C}$ was not found for erythrocytes exposed to the drug in $60 \mathrm{mM} \mathrm{NaCl}$ (Table 2). Generally cells maintained at $20^{\circ} \mathrm{C}$ with $0.1 \mathrm{mM}$ chlorpromazine had a higher incidence of stage III internalized shapes compared with erythrocytes at $37^{\circ} \mathrm{C}$ over the same exposure time (Fig. 1).

Table 1: The Influence Of Membrane Potential On Drug Membrane Association a. The influence of membrane potential on cellular uptake of drugs

\begin{tabular}{|c|c|c|c|c|}
\hline $\begin{array}{l}\text { Drug/nature/ } \\
\text { concentration } \\
(\mathrm{mM})\end{array}$ & $\begin{array}{l}\text { Type of shape } \\
\text { change induced by } \\
\text { drug in } 60 \mathrm{On}-\mathrm{NaCl} \\
\text { at both } 20^{\circ} \mathrm{C} \text { and } \\
37^{\circ} \mathrm{C} \text {. }\end{array}$ & $\begin{array}{l}\text { Time } r \text { of } \\
\text { maximum stage } \\
\text { III/ shapes at } \\
20^{\circ} \mathrm{C} \text { or } 37^{\circ} \mathrm{C} \\
(\mathrm{mm})\end{array}$ & $\begin{array}{l}\text { Change of shape } \\
\text { with temperature } \\
\text { increase after10 } \\
\text { mins at constant } \\
\text { drug concentration } \\
\text { at both } 20^{\circ} \mathrm{C} \text { and } \\
37^{\circ} \mathrm{C}\end{array}$ & $\begin{array}{l}\text { Temperature }\left(20^{\circ} \mathrm{C} \text { or }\right. \\
\left.37^{\circ} \mathrm{C}\right) \text { at which } \\
\text { greater change from } \\
\text { biconcave form was } \\
\text { observed after } \\
30 \text { mins } \\
\text { maintenance. }\end{array}$ \\
\hline $\begin{array}{l}\text { Tetracaine } \\
\text { (cationic drug) } \\
4.0 \\
\text { chlorpromazine } \\
\text { (Cationic drug) }\end{array}$ & $\begin{array}{l}\text { internationalization } \\
\text { externalization } \\
\text { internationalization }\end{array}$ & $\begin{array}{l}0,0 \\
60, ? \\
2,0\end{array}$ & $\begin{array}{ll}\text { away } & \text { from } \\
\text { biconcave } & \\
\text { away } & \text { from } \\
\text { biconcave } & \\
& \end{array}$ & $\begin{array}{l}37>20 \\
20>37 \\
20>37\end{array}$ \\
\hline $\begin{array}{l}\text { benzyl alcohol } \\
\text { (neutral drug) } \\
30.0\end{array}$ & discocyte & $?, ?$ & towards biconcave & $37 \geq 20$ \\
\hline
\end{tabular}

$?=$ not relevant 
Table 2:

The Influence Of Membrane Potential On Drug Membrane Association b: Shape changes of human erythrocytes induced by drugs in buffered $60 \mathrm{mM} \mathrm{NaCl} 5 \mathrm{mM}$ Hepes $85 \mathrm{mM}$ Na gluconate, $\mathrm{pH} 6.94$ at $20^{\circ} \mathrm{C}$ and $37^{\circ} \mathrm{C}$

\begin{tabular}{|l|l|l|l|l|}
\hline $\begin{array}{l}\text { Drug/Concentration } \\
(\mathrm{mM})\end{array}$ & Haematocrit & \multicolumn{2}{|l|}{$\begin{array}{l}\text { Cellular uptake (\%) of drug as } \\
\text { function of membrane potential } \\
( \pm 2 . \text { S.E.M) }\end{array}$} & $\begin{array}{l}\text { Ratio of cellular uptake of } \\
\text { drug for a runstant } \\
\text { erythrocytes in 145mM NaC1 } \\
( \pm 2 \text { S.E.M) }\end{array}$ \\
\cline { 3 - 5 } & & $-7 \mathrm{mV}$ & $16.4 \mathrm{mV}$ & $1.84 \pm 0.6$ \\
Tetracaine 4.0 & 18.4 & $41 \pm 0.27$ & $27.4 \pm 0.16$ & $1.79 \pm 0.1$ \\
Chlorpromazine & 4.3 & $31 \pm 0.05$ & $20.1 \pm 0.4$ & $1.22 \pm 0.1$ \\
Benzyl alcohol & 4.3 & $12 \pm 0.06$ & $10 \pm 0.09$ & \\
\hline
\end{tabular}

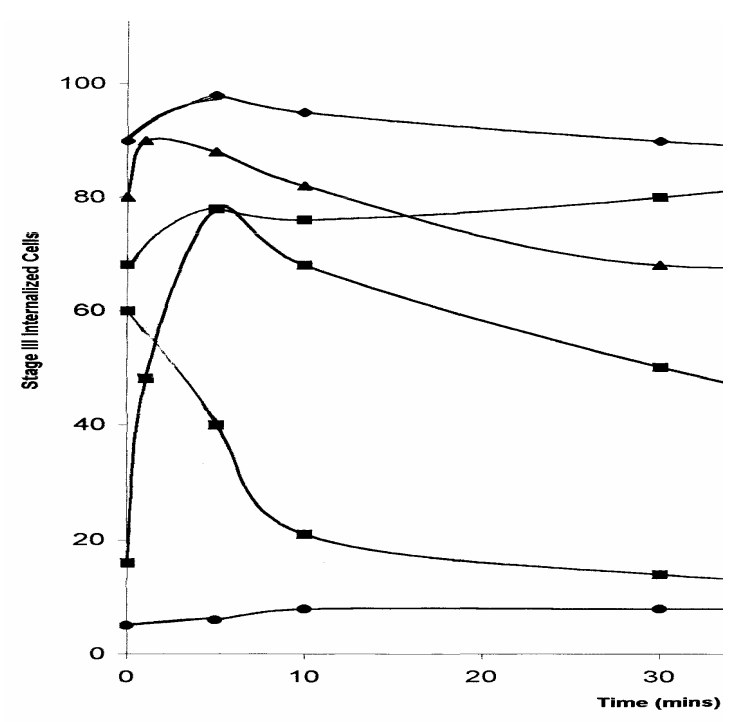

Fig. 1:

The incidence of Stage III internalized cells in cell suspensions held in $0.1 \mathrm{mM}$ chlorpromazine in either $145 \mathrm{mM} \mathrm{NaCl}$ at $20^{\circ} \mathrm{C}\left(\right.$ ) and $37^{\circ} \mathrm{C} \mathrm{(} \mathrm{)} \mathrm{or} 60 \mathrm{mM} \mathrm{NaCl}$ at $20^{\circ} \mathrm{C}$ (and $37^{\circ} \mathrm{C}()()$ or $40 \mathrm{mM} \mathrm{NaC} 1$ at $20^{\circ} \mathrm{C} 4-$ ) and $37^{\circ} \mathrm{C}$ (---) for different times. The results are the average values from Six experiments at each temperature and chloride concentration

Tetracaine: About $35 \%$ of the cells internalized membrane (Stage III stomatocytes) immediately on exposure to $4 \mathrm{mM}$ tetracaine in $6 \mathrm{mM} \mathrm{NaCl}$ at $37^{\circ} \mathrm{C}$ in constant to $70 \%$ in the situation for cells in $145 \mathrm{mN} \mathrm{NaCl}$ with the drug. Cells in both $60 \mathrm{mM} \mathrm{NaCl}$ and $145 \mathrm{mM} \mathrm{NaCl}$ with the drug rapidly decreased their shapes towards a lower incidence of stage III internalized form with time (Fig. 2). After 10 minutes cells exposed to $4 \mathrm{mM}$ tetracaine in $60 \mathrm{mM} \mathrm{NaCl}$ at $20^{\circ} \mathrm{C}$ gradually became externalized. $10 \%$ of the cells showed stage III externalized shape after 60 minutes.

Benzyl alcohol: Fig. 3 shows the incidence of stage III crenation of cells in cell suspensions maintained in $50 \mathrm{mM}$ benzyl alcohol. The initial $(0$ to 2 minutes) high incidence of stage III externalized shapes as $\mathrm{w}$ observed when first exposing cells to changed drugs were not found with benzyl alcohol at either $20^{\circ} \mathrm{C}$ or $37^{\circ} \mathrm{C}$. the erythrocytes maintained with the drug in $60 \mathrm{mM} \mathrm{NaC1}$ showed low incidence of stage III externalized form at $20^{\circ} \mathrm{C}$ and $37^{\circ} \mathrm{C}$ (Fig. 3).

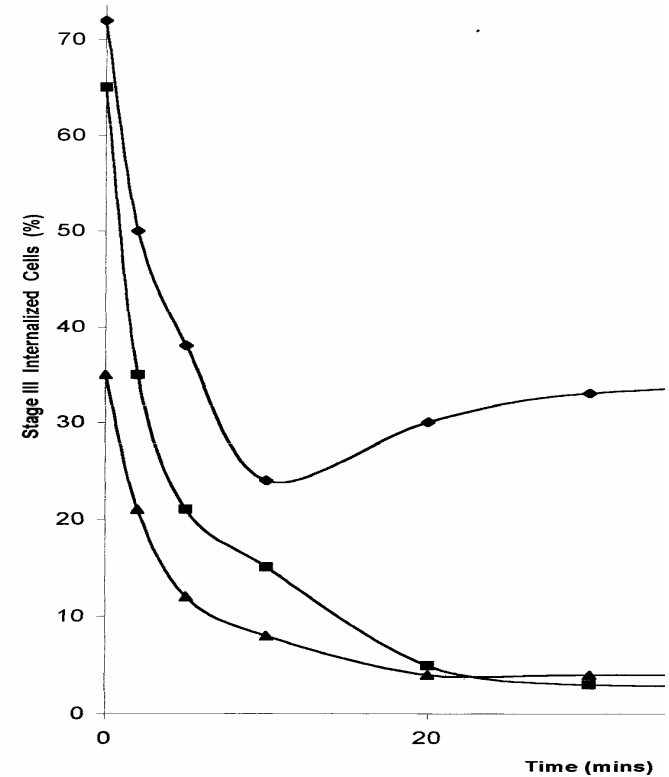

Fig. 2

The incidence of Stage III internalized cells in cell suspensions held in $4 \mathrm{mM}$ tetracaine in $145 \mathrm{mM}$ $\mathrm{NaCl}$ at $20^{\circ} \mathrm{C}(--)$ and $\left.37^{\circ} \mathrm{C} 4\right)$ and in $60 \mathrm{mM}$ $\mathrm{NaCl}$ at $37^{\circ} \mathrm{C}$ (A) for different times. The results are the average values from seven experiments at each temperature and chloride concentrations.

\section{DISCUSSION}

In the present study, a strong influence of extracellular chloride ion concentration $(E$ $=-7.1 \mathrm{mV}$ to $\mathrm{E}=16.4 \mathrm{mV}$ ) on cationic drugs tetracaine and chlorpromazine 
(Fuji et al 1976) and neural drug benzyl alcohol (Deuticke 1968) induced human erythrocytes shape change and on cellular uptake of drug has been established. Decreasing the extracellular chloride ion concentration (Nwafor and Coakley 1991) led, in the case for tetracaine and chlorpromazine to reduce their cup forming property The direction of shape change was reversible through changes in the extracellular chloride ion concentrations.

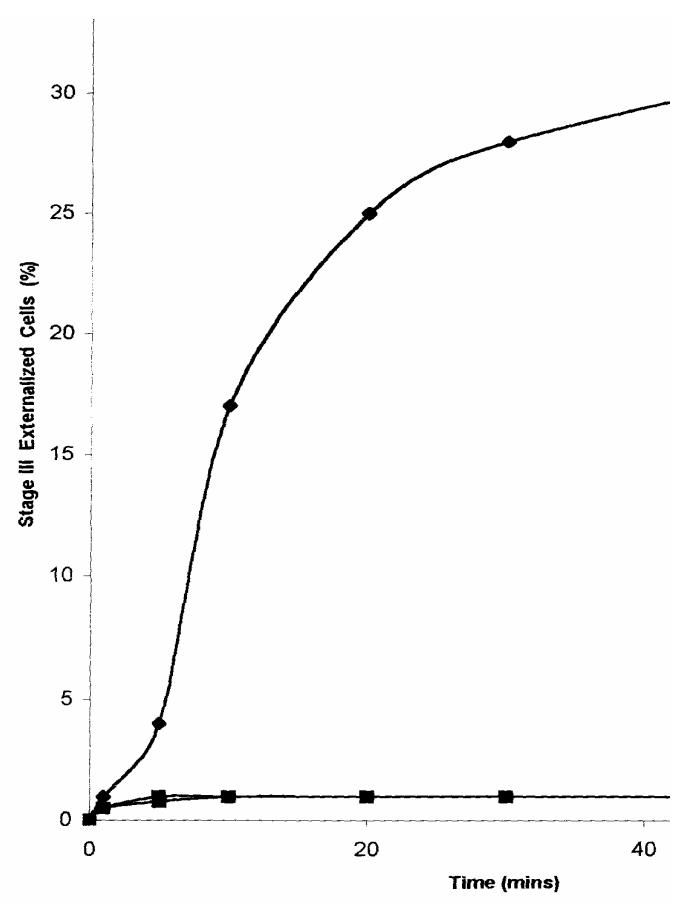

Fig. 3:

The incidence of Stage III externalized cells in cell suspensions maintained in $50 \mathrm{mM}$ benzyl alcohol in either $145 \mathrm{mM} \mathrm{NaCl}$ at $20^{\circ} \mathrm{C}(--)$ and $37^{\circ} \mathrm{C} \mathrm{(-}$

-) or $60 \mathrm{mM} \mathrm{NaCl}$ at $20^{\circ} \mathrm{C}()$ and $37^{\circ} \mathrm{C} \mathrm{(- \bullet -)} \mathrm{for}$ different times. The results are the average values from five experiments at each temperature and chloride concentration.

The study also revealed that unlike charged drugs, $\mathrm{NaCl}$ concentration did not influence the shape changes of human erythrocytes induced by benzyl alcohol at $20^{\circ} \mathrm{C}$. Unlike charged drugs, benzyl alcohol in $145 \mathrm{mM} \mathrm{NaCl}$ at $37^{\circ} \mathrm{C}$ did not show immediate externalization.

At membrane diffusion potential E, $7 \mathrm{mV}$ the cells became increasingly echinocytic (Fuji et al 1979) with time. The slow development of externalization in cells in $145 \mathrm{mM} \mathrm{NaC1}$ with benzyl alcohol at $37^{\circ} \mathrm{C}$ suggest that the development of the echnocytic forms in cells may be due to a slowly developing secondary modification of the bilayer which occurs when the membrane potential is approximately $-7 \mathrm{mV}$ and not when the membrane potential is $16.4 \mathrm{mV}$. The cells in $60 \mathrm{mV} \mathrm{NaCl}(\mathrm{E} 16.4 \mathrm{rnV})$ at $37^{\circ} \mathrm{C}$ were not initially, and did not become echinocytic. These results are consistent with the views that drugs do not penetrate the hydrophobic region of the lipid bilaryer of the cell membrane (Seeman 1972, Kanaho et al 1981). The bilayer couple hypothesis (Sheetz and Singer 1974) was not affected by the above results since it requires only that a differential drug- induced change in the surface free energy at the two faces of the membrane gives rise to a bending couple. Thus the observation that changes in the extracellular chloride concentration which alter the potential across the erythrocyte membrane can modify the morphological consequences of exposure to drug is consistent with the bilayer couple hypothesis (Sheetz and Singer 1974).

Table $\mathrm{lb}$ shows the values of the ratios for the partitioning of tetracaine, chlorpromazine and benzyl alcohol across the membrane when we would expect from the left hand side of equation 3 (Nwafor and Coakley; in press) the ratio to be $145 / 60=2.43$. The results support the view that membrane potential alters the partitioning of drug across the erythrocyte membrane in a manner which is strongly dependent on the chloride ion distribution

The differences in drug membrane interaction at $37^{\circ} \mathrm{C}$ for cells in $60 \mathrm{mM}$ $\mathrm{NaCl}$ or in $145 \mathrm{mM} \mathrm{NaC1}$ with $50 \mathrm{mM}$ benzyl alcohol (Fig. 3) may explain the small differences in drug uptake for different membrane potential (Table 1b). The partitioning of a neutral drug across the membrane would be expected to be independent of membrane potential so that the expected ratio would also be expected to be independent of membrane potential in that the expected ratio would be 1.0 . The ratio 1.22 above (table lb) may reflect potential dependent change in the extent of the interaction of 
the neutral drug with the membrane at $37^{\circ} \mathrm{C}$.

However, study on the possible influence of membrane potential change effects on anionic drugs induced cells shape change and a cellular uptake of drug is needed to reach a definite conclusion.

\section{REFERENCES}

Denticke B. (1968) Transformation and Restoration of bilencave shape of human erythrocytes induced by amphiphilic agents and changes of ionic environment. Biohem. Biophys. Acta 163. 494 - 500.

Fuji, T; Sato T; Tamura, A: Wakatsuki M. Kanalio Y. (1979) shape changes of human erythrocytes induced by various amphiphilic drug acting on the membrane of intact cells. Biochem. Phamacol 28: 613-620.

Glaser R. (1979) The shape of Red blood cell as a function of membrane potential and temperature. J. Membrane Biol. 51: 217-228.
Glaser R. (1982) Echinocyte formation induced by potential changes of human red blood cell. J. membrane Biol. 66: 79-85.

Kanaho Y. Sato T, and Fujii T. (1981) The affinity of various phenothiazine drugs for membrane of intact human erythrocytes and their membrane transforming activity Mol. Pharma 20: $704-708$ of phenothiazine. Blood cells 1; 375-384.

Nwafor A. and Coakley W. T. (1985) Drug induced shape in erythrocytes correlates with membrane potential change and is independent of glucocalyx. Biochem. Pharm. 34: 3328-3336.

Nwafor A. and Coakley W. T. (1991) The effect of elevated temperature on drug and premembrane potential change on the fragmentation of human red blood cells Nig. Physiol Sci.7: 8-11.

Seernan P. (1972) Membrane actions of anaethetic and tranquilizers. Pharmacol. Rev. 24 583-655.

Sheetz M. P. and Singer S. J. (1974) Biological membranes as bilayer couples. A molecular mechanism of drug-erythrocyte interaction Proc. Natl. Acad. Sci. USA 71: $4457-4461$.

Received: September 2001

Accepted in final form: August 2002 